\title{
Whither the Solidarity? Opportunity in Crisis: The Eurozone Crisis and the Future of European Integration
}

\author{
By Christianna Nichols Leahy*
}

The on-going eurozone crisis has inspired cynics to ask, is the European Union broken, or just broke.' Alarmist titles such as Is the EU Doomed? and After the Fall: The End of the European Dream and the Decline of a Continent fill the bookshelves of Eurosceptics. Rather than despair, some view the crisis as an opportunity for genuine democratization from the bottom up as a means to revive the European project and the ideals envisioned by its inspirational founders. The eurozone economic crisis has exposed the political crisis that has been festering long before the conversion to the single currency. The chaos caused by the crisis has revealed a profound lack of democratic legitimacy as well as a fundamental undermining of European solidarity that was to be the foundation of European integration. The challenges, many of which pre-date the eurozone crisis, have only served to magnify and reinforce the need for creative solutions to the malaise. The challenges are not just economic, but political, institutional, societal, and international. The crisis has led to a loss of legitimacy and to two contrasting views of Europe: the Europe that has come about in the wake of the eurozone crisis, or a new model of Europe that revives and reinvigorates European solidarity. The initial integration of Europe was a topdown process. It is time for civil society to reconstruct European integration from the bottom up, and from the subterranean politics that has reveled itself so clearly in the countries most affected by the eurozone crisis.

\section{Introduction}

The Schuman Declaration creating the European Coal and Steel Community proclaimed that 'Europe will not be made all at once, or according to a single plan, it will be built through concrete achievements which first create de facto solidarity.' The eurozone crisis has cynics wondering whither the solidarity? The economic crisis has exposed the profound political crisis that has been festering long before the conversion to a single currency. In turn, the economic crisis has revealed a democratic crisis that stems from a profound lack of democratic legitimacy, an unsustainable economic union, and the

${ }^{*}$ Professor, McDaniel College, USA. 
fraying of ties of solidarity. Lest Europeans loose sight of the fact that integration has been one of the noblest achievements towards Kant's idea of a cosmopolitan peace, the crisis must be addressed immediately and creatively. The Nobel Peace Prize Committee wanted to remind the eurosceptics of that achievement by awarding the 2012 Nobel Peace Prize to the European Union. In its rationale for the prize, the Nobel committee focused on what it views as the most important byproduct of European integration, namely, the 'successful struggle for peace, reconciliation and for democracy and human rights.' The committee went on to commend the European Union as representing fraternity between nations-amounting to a form of the 'peace congresses' the likes of which Alfred Nobel refers to in his last will and testament as a criteria for the prize.

Countless think tanks have engaged in analysis of the crisis. Several groups have come forward with manifestos outlining concrete solutions to the anomie. Many notables (heads of states and governments, public intellectuals, and EU elites) have affixed their names to proposals for a solution. All bemoan the loss of solidarity and most agree that the single currency rather than cementing European solidarity has revived some of the old enmities between European nations. Rather than reducing disparities of wealth, the eurozone crisis has elevated some nations to the core (Germany) and consigned other nations (the so-called PIIGS) to the periphery. Instead of manifesting Monnet and Schuman's vision of a Commonwealth of Europe and constitutional patriotism, the eurozone crisis has muted transnational solidarity and threatens the entire project of European integration.

Critics of Europe in light of the eurozone crisis such as, Giandomenico Majone, argue that whatever European Union elites believe, more and more citizens view the EU and its institutions 'less as potential sources of solutions for problems that cannot be solved at the national level, than as causes of those problems' (Majone, 2012). The crisis has fueled a sense of a loss of legitimacy and has created contrasting notions of Europe per se. One notion is that of the Europe mutated by the eurozone crisis-the Europe of the Troika led by Germany exerting fiscal dominance. The other is the conception of a new European model that revives and reinvigorates European solidarity from the bottom up in democratic fashion. The latter is the one that Ulrich Beck and the signatories to the We Are Europe Manifesto! envision through the revived model of transnational social democracy (Beck \& Cohn-Bendit n.d.).

The signatories to that particular Manifesto imagine a European Spring that challenges and ultimately defeats the neoliberal version of Europe that has wreaked so much havoc that the Union has lost legitimacy in the eyes of its citizens. The original project of European integration was a top-down process; the signatories view the antidote to that process as a bottom up one. The subtitle of the We are Europe Manifesto is Rebuilding Europe from the Bottom Up. Whereas the vision of Schumann and Monnet was predicated on building Europe from the top down, several manifestos propose the bottom up solution. The integration that the founders began was from the outset based on the belief that endowing supranational institutions with powers insulated from 
democratic control would cement democratic regimes at the national level ensuring that Europe would never again succumb to the temptation of competing nationalisms and the extremist regimes they inspire. Ironically, the eurozone crisis and its attendant political crisis has allowed extreme nationalist parties to enter the European parliament in far greater numbers than ever in the May 2014 elections.

In The End of the European Dream, Stefan Auer argues that the first decades of European integration produced what Thomas Mann advocated in the 1950's, 'a European Germany in a politically unified continent,' yet,' the reunification of Germany caused such trepidation to Europeans that they believed it imperative to reinforce Germany's commitment to Europe through the mechanism of a single currency'(Auer 2013). No one can deny the critical role Germany has indeed, played during this crisis. The onus of action and reaction to the eurozone crisis has fallen upon Germany as the largest and most robust economy in Europe. The tightening of fiscal policy approach that Germany has imposed during the crisis is one centered on austerity and price stability at the expense of economic growth. This tradeoff is at the center of the devastation that the crisis has wrought.

\section{Ordoliberalism - The Austerity Obsession and its Effects}

In a policy brief published by the European Council on Foreign Relations entitled, 'The Long Shadow of Ordoliberalism: Germany's Approach to the Euro Crisis,' Sebastian Duillien and Ulrike Guerrot argue that Germany's response to the eurozone crisis is part of a particular variant of German economic orthodoxy (with which many in Europe vehemently disagree). The formula is termed Ordoliberalism. Its doctrine makes monetary stability sacrosanct. Germany's Constitutional Court agreed ruling that the eurozone bailout was in fact legal, as long as the German parliament had enough supervision rights. Ominously, Chancellor Merkel has termed this gospel of austerity formula 'market-conforming democracy.' Ironically, as the European Trade Institute explains it: 'we have moved, in the space of four years, from a financial capitalism judged non-compliant with the demands of democracy, to a democracy judged non-compliant with the demands of the financial markets' (European Trade Union Institute 2013).

Even the Economist describing the effects of austerity on Greece in April of 2011 complained that 'such a retrenchment was on an unprecedented scale in recent European history' (Economist 2011). In the major public health study entitled, The Body Economic: Why Austerity Kills: Recessions, Budget Battles and The Politics of Life and Death the authors (physicians and academics) having gathered data from around the world, concluded that austerity policies create epidemics that have devastating and disastrous effects on human health. Panayota Gounari terms the obsession with neoliberal austerity policies a form of 'social necrophilia' that she defines as an organized effort on the part of the 
national political system and the foreign neo-liberal TROIKA 'to implement economic policies and austerity measures that result in the physical, material, social and financial destruction of human beings: policies that promote death, whether physical or symbolic' (Gounari 2014).

Between the immiserization of the people of the periphery and the curtailment of democracy at the national and European levels of governance (namely, via the Troika, an unelected body), the European Union has for all intents and purposes turned into a sovereign entity with complete authority to impose structural reforms, austerity measures, and budgetary rules on member states in the absence of democratic procedure (Fazi 2014). This fundamental shift has undermined the social democratic postwar consensus in radically destructive ways.

In response to the fraying of the postwar consensus, another group of notable scholars and Europeanist have authored a manifesto, entitled We Need a Europe That is Truly Social Democratic: The Case for a Fundamental Reform of the European Union. They make the argument that the issue at stake is no longer 'how can the democratic legitimacy of the EU institutions be strengthened?' but rather, 'how can we preserve the substance of democracy in Europe?'(Nida-Rumelin, Hirschel \& Meyer 2013). They argue for a comprehensive review and a reinforcing of the fundamental connections between the social and political order that needs to be reflected in the institutions that constitute Europe (a European Union, that is built upon democracy, solidarity and justice). That Herculean task has now become one of 'conserving the best features of the social-democratic settlement-which, economically speaking, would 'require changing everything, so everything can remain the same-developing a new vision of the left' that would move it away from the complacency that has marked it for decades (Meaney \& Mounk 2014).

The task of reviving social democracy was one that Tony Judt addressed in many of his last musings. In Il Fares the Land, he lamented the fact that after the discrediting of Marxism, Europeans became, in his view, 'unable to conceive of alternatives' and with no alternative vision to which to aspire, many have 'come to think of even the most obviously unjust aspects of our contemporary economic order as inevitable' (Meaney \& Mounk 2014). Questioning the inevitability of such a premise becomes the duty of those committed to a social democratic Europe. The crisis then, is indeed far more threatening than merely exits from the eurozone. The entire project of European integration is under assault. Only the people of Europe acting in solidarity to reprioritize social democracy can stop that assault.

\section{Proposals for an Economic Fix}

In yet another manifesto, this one entitled, European Solidarity Manifesto, its esteemed authors and signatories offer a radically different fix. The authors agree that the eurozone crisis threatens not only European solidarity, but that it 
is a threat to the European Union and the common market itself. They propose the 'controlled segmentation of the Eurozone via a jointly agreed exit of the most competitive countries with the euro remaining for the less competitive national economies'(European Solidarity Manifesto 2013) The signatories argue that this is the best chance of saving the union and revitalizing European solidarity. Their plan envisions an ultimate return to national currencies or to a different currency or groups of currencies. They argue that this would mitigate the collapse of the banking systems that would no doubt occur if the PIIGS, (Portugal, Italy, Ireland, Greece, and Spain) responding to public pressure, were to exit the Eurozone unilaterally.

Fear of a disorderly exit from the eurozone by the PIIGS was one that George Soros has been concerned about during this crisis. In a piece in The New York Review of Books (just a few months before that manifesto) George Soros had argued that 'Germany must lead or leave.' Obviously Soros was hoping to get a strong response to this provocative salvo, but he was serious. While he realized that a negotiated separation would require a treaty that might take a great deal of time, he believed then that the alternative would have been more palatable than merely allowing the euro to 'disintegrate in a disorderly manner'(Soros 2012). The other option he presented at the time was for Germany to behave as a more 'benevolent hegemon' by establishing a considerably more level playing field between debtor and creditor countries (noting that this would, of course, entail a higher level of inflation than the Budensbank might approve).

By April 2014 Soros changed his tune regarding a German exit because Chancellor Merkel's clear mandate from the German electorate in German parliamentary elections made him realize that her fiscal policies would continue unabated. The German election results clearly exposed the naïveté of his earlier proposal. More of the same fiscal policies and the prospect of the stagnation that will continue as a result, have in Soros' mind set off an adverse political dynamic to the effect that any critics of the existing arrangements are now cast as anti-European integration. Soros confirms that he wants to arrest the process of disintegration, not to accelerate it. Indeed, he too prophesizes a series of political rather than mere financial crises to come (Soros \& Schmitz 2014).

Interestingly, there are also economists on the left who have come to the conclusion that the eurozone-if not the European Union per se, is on its deathbed and that only its orderly dissolution can save Europe from even harsher austerity. Usually such histrionics come from nationalists on the extreme right, but many on the left are now portending that is 'naïve, wishful thinking, and unrealistic, if not an outright dream' to transform the European Union from within and from the bottom up in order to save the project of European integration (Kouvelakis 2013). Costas Lapavitsas and Heiner Flassbeck make the argument that a return to national currencies would allow the periphery member states to regain monetary sovereignty and increase exports by being able to devalue their currencies which would, they argue, 
allow them to regain the right to engage in fiscal stimulus programs rather than wage compression and internal devaluation (Lapavitsas \& Flassbeck 2013).

They underestimate the myriad other problems that such an exit would wreak on the periphery states (among them: being cut off from international capital markets, the need to rely on revenues to finance expenses, not to mention the buying up of national assets at fire sale prices). In their defense, they note that theirs would be a 'progressive exit' based on public ownership and public control over financial institutions, control over capital flows, income and wealth growth, and total restructuring of the state in a democratic direction'((Lapavitsas \& Flassbeck 2013, p.135). One wonders who is naïve and unrealistic now?

A radical leftist proposal for reform and a deeply transformative one is that offered by Thomas Fazi who proposes a radical reform of the monetary union in a democratic, federalist, and progressive direction. The best way this can be achieved is by the citizens of Europe 'actively (and more critically) engaging with the ongoing integration process in order to steer it towards a genuine European supranational democracy' (Fazi 2014). Fazi anchors himself with the progressive or realist federalists whose beliefs are reminiscent of radical twentieth century federalists such as, Altiero Spinelli declaring that 'the root of the euro crisis is mainly political, not economic'(Fazi 2014). Rather than criticize European integration as it stands, its citizens must work to radically democratize and re-politicize, its institutions and the eurozone in order to build a genuine European supranational democracy one that is not based on a 'quasimessianic faith' (Weiler 2011) in Europe. Instead it would be one based on reason and rational consensus by the citizens of Europe who will realize that it is only through a democratic politically united Europe that its citizens can guarantee their rights and curb the overwhelming power of global financial and "corporate leviathans thus regaining at supra-national level the democratically legitimated sovereignty that has been slowly but steadily eroded at the national level (or rather usurped by those financial and corporate powers)' (Fazi 2014).

As with many of the manifestos regarding reform, Fazi's program envisions substantial grassroots, subterranean politics and engagement of panEuropean civil society organizations to build a broad social consensus for the kind of radical bottom up reform necessary to revitalize the union. Fazi passionately concludes his 'manifesto' with 'however we look at it the struggle starts from the bottom up. Europe has been hijacked. It's time to take it back'(' (Fazi 2014, p.128).

\section{Neoliberalism and the Crisis}

By identifying Neoliberalism as the culprit in the overall economic crisis of the new century, Henry Geroux draws similar conclusions to that of many European thinkers such as Fazi. While not writing specifically about the eurozone crisis, his analysis resonates. He argues that with its 'theatre of cruelty and mode of public pedagogy,' Neoliberalism constitutes a form of 
'economic Darwinism' that attempts to 'undermine all forms of solidarity capable of challenging market-driven values... promoting virtues of unbridled individualism almost pathological in its distain for community, social responsibility, public values and the public good (Geroux 2014) Thomas Palley agrees. He attributes the eurozone crisis to the consequence of 'a toxic neoliberal economic policy cocktail' that undermined the income and demand generation process by wage stagnation that widened income inequality (Palley 2013). The topic of widening income inequality has had a much-needed renaissance in light of the global financial crisis and it has a brilliant prophet in Thomas Piketty.

While best known for his critically acclaimed tome, Capital in the Twentyfirst Century, Piketty also offers some pragmatic ideas for reforming European financial structures. He proposes how a functional and democratic eurozone might work- having a joint eurozone debt with a 'budget chamber', composed of national elected members of parliament that would debate and vote common and binding debt ceilings. Such a chamber would bring Members of Parliament from finance and social affairs commissions of national parliaments who would decide by majority vote (after a public debate on a proposal from a European finance minister accountable to that chamber), the volume of common public debt that the European treasury would emit each year (with the important provision that each national parliament would remain entirely free on the overall level of taxing, spending and distribution) (Willy 2012). This solution alone would contribute to the re-democratization of decision-making of fiscal policy within the European Union. Piketty also proposes a European tax on wealth.

Martin Wolf writing in the Financial Times notes what many economists argue concerning the future of Europe, namely, that inequality unequivocally damages the economy (Piketty goes so far as to argue that it challenges democracy as well) (Piketty2014). He along with Piketty argue that contrary to neoliberal arguments a more equal society will not hinder growth and efforts to remedy inequality are, on the whole, not harmful to economic growth. Guy Standing describes the scourge of inequality of recent decades not simply as an increase in inequality, but as the 'emergence of a new globalized class structure' containing a new class- the precariat. The new precariat class is comprised of individuals who 'lack economic security or stable occupational identities so much so that they become 'systematically deprived of some of the fundamental rights afforded to citizens (Standing 2014). Standing proposes a Precariat Charter one that would restore the fundamental civil, cultural, political and economic rights that global inequality, particularly as expressed in policies of austerity has robbed them of in Europe as well as elsewhere. As Standing envisions it: 'the assets underpinning a Precariat Charter are basic security, control of time, quality, space, education, financial knowledge, and financial citizenship... without which none of us can be expected to be socially responsible' (Standing 2014).

\section{The Precariat in the 2014 European Elections}


Once could argue that it is the precariat who gained so many seats in the May 2014 elections to the European Parliament. Whether coming from the ranks of Marine Le Pen's Front National, the United Kingdom Independence Party, Greece's Golden Dawn on the right, or Syriza's substantial victory on the radical left in Greece, the appeal of these diverse parties was to the precariat. The pensioners, the unemployed, the marginalized and those who sense the usurpation of power by elites in Brussels and Strasbourg form the ranks of the European precariat. Highly susceptible to populist and nationalist rhetoric out of frustration with inaction by elites in dealing with the crisis and the fear of even worse economic times to come, the European precariat was successfully mobilized for the election. Although voter turnout was still under fifty per cent, the electorate of the extremes spoke loudly if not so clearly. Despite the overwhelming press coverage emphasizing the Eurosceptics, anti immigrant and extreme right victories in France and the U.K., extremists in the Netherlands did not fare as well as many feared nor did the extremists in Italy. In Portugal one of the PIIGS of the austerity-laden periphery, the opposition Socialists fared very well. Spain's anti austerity but pro European party Podemos 'We Can' (that grew out of the Indignados movement) also fared remarkably well with eight per cent of the vote and five seats in parliament despite the fact that it was formed just four months before. While it might appear rather naïve to see the victory of Syriza in Greece as evidence of the possibility of mobilizing not along racist, facile anti-immigrant sentiment, but along constructive lines of solidarity and alternative economic policies, it is possible that such an alternative could take hold. Given the composition of the new European parliament, however, that is highly unlikely. If the United States Congress has been the epitome of rancor and gridlock, the new EU Parliament looks to be one that will emulate the worst qualities of its counterpart in the United States.

\section{European Spring}

Since many economists have been analyzing the eurozone crisis in terms of faulty decision-making by the European Central Bank and the European Commission, perhaps there is enough data now to justify an alternative course of action to austerity. Philippe Legrain makes the argument that Europe's banking problems were not addressed before the single currency and as a result plagued it from the beginning. Legrain vehemently argues that 'we need to dispel bad ideas such as the austerity delusion, the competitiveness myth, the bubble mentality and the notion that economies are inherently stable and predictable' (Legrain 2014). In his latest book, European Spring: Why Our Economies and Politics are a Mess- and How to Put Them Right,' he too offers the vision of a reinvigoration of social democracy and reform rather than the abandonment of integration and of the European project. 
While Legrain metaphorically calls for a European Spring, the signatories to the We Are Europe! Manifesto's call for a European Spring and offer concrete policy recommendations. Beck and the other signatories to the manifesto propose a year of volunteering in Europe to create a European civil society united in its commitment to European social democracy. They echo John F. Kennedy's transformative call to service rephrasing it as, 'ask not what Europe can do for you; ask what you can do for Europe (We are Europe! Manifesto for Re-Building Europe From The Bottom Up 2013). In their manifesto they ask the European Commission and national governments, the European Parliament and national parliaments to create a 'Europe of actively employed citizens and to secure the financial and legal requirements for the European Year of Volunteering for Everyone as a counter-model to the topdown Europe, the Europe of elites and technocrats' (We are Europe! Manifesto for Re-Building Europe From The Bottom Up 2013). This 'European Peace Corps' proposal would also address the issues of massive youth unemployment and invigorate pan-European civil society giving it a vibrant voice. They would draw on existing structures such as the European Voluntary Service and Erasmus for All while also expanding on them in ways that foster a Europe from the bottom up- re-energized by civil society.

Another manifesto with very specific policy recommendations is that offered by a group of Spanish economists under the banner Economistas Frente a la Crisis. They offer ten steps for the revival of the European Economy. As in the case in many of the manifestos, they call for reducing unemployment, reforms in financial governance, (e.g. a banking union and the sharing of risks), reforms in monetary policy (e.g. a European Central Bank 'at the service of economic and social cohesion),' reforms in political governance (e.g. rebalancing powers to redress the democracy deficit), completion of the social pillar, environmental policies as a leverage for economic growth, and other concrete steps. (de la Rocha-Vazquez 2014)

Others have offered quick interim solutions to the economic component of the crisis. Yani Varoufakis, Stuart Holland and James K. Galbraith offer four policies that could be implemented within existing European law and treaties. Turning troubled banks to the European Stabilization Mechanism that would be empowered to directly, completely and unconditionally recapitalize or restructure them is the first policy proposal. A limited debt conversion program with the European Central Bank offering debtor member states the opportunity to convert the portion of their debt that is below the sixty per cent debt-to-GDP limit to a favorable lower interest rate is another. The third component envisions an investment led recovery and convergence program with the European Investment Bank and the European Investment Fund issuing bonds jointly to finance social and environmental investments without adding more debt. The final recommendation is for an emergency solidarity program to guarantee access to nutrition and basic energy needs for all citizens of Europe that would be funded by the European Commission using the interest accumulated within the European system of central banks, profits from 
government bond transactions, and other financial transactions (Varoufakis, Holland \& Galbraith 2013).

While such reforms may appear unrealistic, a consortium of eleven European Foundations have been promoting Europe-wide reform by developing what they deem to be 'realistic' reform proposals for the EU leadership that will take office following the May 2014 European elections. Their New Pact for Europe identifies four key challenges facing Europe. The socio-economic dimension addresses the threats to social peace that the economic aspect of the crisis has exacerbated. Closely related is the societal dimension that addresses the increasing divide between member states and the reversion to nostalgia for national sovereignty that the parties of the far right have inflamed. The political-institutional dimension addresses the lack of public support or buy in for the European Union per se. The last is the externalglobal dimension of the international economic system and the need to address the issues of global governance in ways that minimize the risk of the gradual marginalization of Europe in international affairs. The authors do not provide a set of conclusions or more specific recommendations but through the series of discussions in member states with some fifty forums, they hope that the feedback they can then provide to the EU leadership assuming office after the elections in May 2014 will be useful.

\section{Conclusion}

Suffice it to say the crisis clearly does not suffer from lack of attention. All of the sophisticated critical economic analyses of the causes, the many manifestos offering solutions and the astonishing number of books it has generated by some of the most revered Europeanists are evidence of the deep and abiding concern for the future of Europe. The extremes of left and right currently appear to about one another as they denounce the undemocratic technocrats who have usurped so much power. Their electoral gains in the May 2014 elections to the European Parliament register the skepticism that any viable solutions are close at hand. Although it is interesting to note that while the extremes of the far right did very well in France, the United Kingdom and Denmark; in all of the PIIGS (Portugal, Italy, Ireland, Greece and Spain, the left pro European Union parties also did well and on the whole and the pro European parties of the center still comprise the largest number of Members of the European Parliament.

As failed and imperfect as the current state of Europe is, it has created, the preconditions for realizing a more far-reaching goal of the construction of political decision making at the supranational level. Habermas argues that the eurozone crisis has helped to shatter neoliberal illusions and has helped to foster 'the insight that the financial markets-indeed, more generally, the functional systems of world society whose influence permeates national borders-are giving rise to problems that individual states, or coalitions of states, are no longer able to master' (Habermas 2012). Climate change is certainly one 
issue that comes to mind here along with other transnational issues that the European Union addresses.

Habermas echoes the clarion call of 'Another Europe is Possible.' Whether it is through a European Citizens Charter of the Commons (initiated in Rome), or The New Deal for Europe that the European Citizen's Initiative for a European Special Plan for Sustainable Development and Employment calls for, or that proposed by the European United Left/Nordic Green Left, or the Party of The European Left that elected Alexis Tsipras as a candidate for the Presidency of the European Commission, or through a Green New Deal, all agree that the neoliberal doctrine must be challenged vigorously. The consensus is that neoliberal free-market fundamentalism with its financial deregulation and unequal trade policies have caused 'divergences and imbalances between the European economies (dividing the continent into creditor and debtor countries) that have now reached unprecedented and unsustainable proportions' (Fazi 2014). As Thomas Fazi explains, the crisis of Europe is part of the larger global crisis of Neoliberalism that over the course of three decades 'has brought about more inequality, insecurity, and instability, at the expense of social welfare and labor rights, and it is now tearing apart the fabric of our democracies... as well as threatening the future of the European integration process' (Fazi 2014).

The Nobel Prize winning economist Paul Krugman cautions that even if there is economic recovery, it will not be enough. He scolds Europe's elite noting that they need to remember what the European project was intended to be in the first place, a vehicle for human rights and democracy. Krugman finds it terrifying to see so many Europeans rejecting democratic values. He places part of the blame on the officials who 'seem more interested in price stability and fiscal probity than in democracy'(Krugman 2014). The larger issue then is what kind of democracy will emerge from this crisis? Will the opportunity it presents for reform and revitalization of European integration-not just fiscally or monetarily- but politically and socially be seized upon with creativity, reason and passion? Can the citizens of Europe orchestrate a 'polyphonic Europe that embraces the principles of democracy, plurality and selfgovernment' (as advocated by Zielonka 2014)?

The various approaches to the crisis examined here offer a plethora of creative ideas for reform of the European Union. It is now up to the newly elected European institutions to forge ahead with serious policies to remedy not only the eurozone crisis, but also the larger existential crisis that the economic crisis has revealed. Needless to say, given the electoral results, that is going to be a formidable challenge. In the same sense that Robert Schuman declared that world peace 'cannot be safeguarded without the making of creative efforts proportionate to the dangers which threaten it,' (Schuman 1950) likewise, today Europe cannot be safeguarded without the making of creative efforts proportionate to the dangers that threaten it. The threat to economic prosperity, let alone to European solidarity and democracy is now greater than ever. Given the composition of the new European parliament, the only remedy is the 
massive mobilization from the bottom up by the citizens of Europe in solidarity with one another and in opposition to destructive extremist forces. The challenge is a daunting one but so were the challenges in the postwar ruins from which the union was founded.

\section{References}

Auer, S. 2013 The End of the European Dream: What Future for Europe's Constrained Democracy, Eurozine. DOI= http://www.eurozine.com/articles/20 13-02-22-auer-en.html

Beck, U. and Cohn-Bendit, D. We Are Europe! Manifesto for Rebuilding Europe from the Bottom Up. DOI= http://manifest-europa.eu/allgemein/wir-sindeuropa?Lang =en

de la Rocha-Vazquez, M. 2014. Ten Steps To Revive the European Economy. Social Europe Journal. DOI= http://www.social- europe.eu/2014/04/revive-europeaneconomy/

Economist. 2011. Greece's economic woes: the labours of austerity. (April 7, 2011). DOI $=\underline{\text { http://www.economist.com/node/18529697 }}$

European Solidarity Manifesto: An Alternative Solution to the Eurozone Crisis. 2013. (Brussels, January 24, 2013). DOI= http://www.european- solidarity.eu/esm. php

European Trade Union Institute. 2013. Benchmarking Working Europe 2013. 7. DOI= http://www.etui.org/Publications2/Books/Benchmarking-Working-Europe-2013

Fazi, T. (2014). The Battle for Europe: How an Elite Hijacked a Continent and How We Can Take it Back. Pluto Press, London, UK.

Gounari, P. 2014. Neo-liberalism as Social Necrophilia: The Case of Greece. Truthout. DOI= http://www.truth-out.org/news/item/22584-neoliberalism- as-so cial-necrophilia-the-case-of-greece

Geroux, H. 2014. Beyond Neoliberal Mis education. Truthout. DOI= http://www. truth-out.org/opinion/item/22548-henry-giroux-beyond-neoliberal-miseduca tion

Habermas, J. 2012. The Crisis of The European Union: A Response, Translated from the German by Cronin, Ciaran. Polity Press, Cambridge, U.K.

Kouvelakis, S. 2013. The End of Europeanism, introduction to Costas Lapavitsas. Crisis in the Eurozone. Verso, London, UK.

Krugman, P. 2014. Crisis of the Eurocrats. New York Times. (May. 22, 2014). DOI= http://www.nytimes.com/2014/05/23/opinion/krugman-crisis-of-the-eurocrats

Lapavitsas, C and Flassbeck, H. 2013. The Systemic Crisis of the Euro-True Causes and Effective Therapies. 2013. Rosa-Luxemburg-Stiftung, Berlin, Germany. (May 2013).

Legrain, P. 2014. The Eurozone Crisis Has Tipped Many Into Disillusionment, Despair and Extremism-We Need a 'European Spring. The Independent. (May 25, 2014). DOI= http://www.independent.co.uk/news/world/europe/philippe-leg rain-the-need-a-european-spring-9278743.html?origin=internalSearch

Majone, G. 2012 Rethinking European Integration After the Debt Crisis, Working Paper No. 3. The European Institute, University College of London. DOI= http://www.ucl.ac.uk/european-institute/analysispublications/publications/WP3.pdf

Meaney, T. and Mounk, Y. 2014. What Was Democracy? The Nation. (Jun. 2003). 24-36. DOI= http://www.thenation.com/article/179851/what-was- democracy

Nida-Rumelin, J., Hirschel, D. and Meyer, H. 2013. We need a Europe that is truly Social and Democratic: The Case for a Fundamental Reform of the European 
Union. Social Europe Occasional Paper.7. DOI= http://www.social-europe.eu/op3-we-need-a-europe-that-is-truly-social-and-democratic/

Palley, T. 2013. Europe's Crisis Without End: The Consequences of neo-liberalism Run Amok. March, 2013 Working Paper- Macroeconomic Policy Institute. DOI $=\underline{\text { http: } / / \text { www.boeckler.de/pdf/p_imk_wp_111_2013 }}$

Piketty, T. 2014.Capital in the Twenty-first Century. Translated by Arthur Goldhammer. Harvard, Cambridge, MA.

Soros, G. 2012. Germany and the Euro: In Response to 'The Tragedy of the European Union and How to Resolve It. The New York Review of Books. October 25, 2012). DOI=http://www.nybooks.com/search/?q=George+Soros+Germany+and+ the+Euro\&origin $=$ magazine

Soros, G. and Schmitz, P. G. The Future of Europe: An Interview with George Soros. (2014) The New Your Review of Books. (April 24, 2014).

Standing, G. 2014 How to Combat Inequalities Produced by Global Capitalism. Social Europe Journal. DOI= http://www.social-europe.eu/2014/05/combat-ine qualities-insecurities-produced-global-capitalism/

We are Europe! Manifesto for Re-Building Europe From The Bottom Up. (2013). DOI= http://manifest-europa.eu/category/allgemein?lang=en

Schuman, R. 1950. The Schuman Declaration. DOI= http://europa.eu/about-eu/basicinformation/symbols/europe-day/schuman-declaration/

Varoufakis, Y. Holland, S. and Galbraith, J.K. A Modest Proposal for Resolving the Eurozone Crisis-Version 4.0. (2013). DOI= http://yanisvaroufakis.eu/euro-crisis/ modest-proposal/

Weiler, J. (2011). The Political and Legal Culture of European Integration: An Explorative Essay. International Journal of Constitutional Law 9. (nos. 3-

4 , 678-94).

Willy, C. 2012. Thomas Piketty: A Plan for a Working and Democratic Eurozone. (September 5, 2012). DOI= http://www.craigwilly.info/2012/09/05/ thomas-piket ty-a-plan-for-a-working-and-democratic 
